\title{
COMPARISON OF THE PORT AUTHORITY'S EFFICIENCY IN TURKEY
}

\author{
DOI: 10.17261/Pressacademia.2017.459 \\ JMML- V.4-ISS.2-2017(8)-p.152-158
}

Irmak Daldır ${ }^{1}$, Omur Tosun ${ }^{2}$

Akdeniz University, Antalya, Turkey. irmakdaldir@akdeniz.edu.tr

Akdeniz University, Antalya, Turkey. omurtosun@akdeniz.edu.tr

\section{To cite this document}

Daldir I and O.Tosun, (2017). Comparison of the port authority's efficiency in Turkey. Journal of Management, Marketing and Logistics (JMML), V.4, Iss.2, p.152-158.

Permemant link to this document: $\underline{h t t p: / / d o i . o r g / 10.17261 / P r e s s a c a d e m i a .2017 .459 ~}$

Copyright: Published by PressAcademia and limited licenced re-use rights only.

\begin{abstract} port management. port authority's efficiencies are compared with data envelopment analysis. are shared.

Keywords: Efficiency, seaport, productivity, data envelopment analysis.

JEL Codes: C44, L25, M10
\end{abstract}

Purpose- The ports, which are a gateway to international trade, directly affects the country's economy, so their efficiency has vital role for all countries. With the scarce resources, effective usage of inputs become important. Input factors like terminal area or number of docks are hard to improve or if possible are very cost-oriented. Therefore, using this limited factors to their maximum capacity becomes one of the main problem in

Methodology- In order to increase ports efficiency, firstly their actual performances should be determined. With respect to this aspect, in this study

Findings- Ambarlı and İzmir port authorities are found as the most efficient and İskenderun is found as least efficient one.

Conclusion: Performance measurement is the first step to improve performance. In this study, port authority's efficiency is compared and results

\section{INTRODUCTION}

Nowadays, negativeness of globalization began to discussed as well as its benefits, but it can be still described as an important factor for world economy. Economic growth's lowest levels are observed after the economic crisis in 2016 (Berksoy, 2016). Expectations for 2017 are more optimistic and 2.7\% economic growth was predicted by the World Bank (The World Bank, 2017). Economic stagnation and crises can sometimes lead to be a warning to companies to review their processes and reduce their wastes. The firms which are able to use this situation for their benefit and strengthen their infrastructure could make use of economic distress as an advantage. A firm which uses airline for their goods transport instead of well-conceived transport plans, could need cut down expenses during economic distress and could benefit from it such as preferring maritime transport with better coordinated planning. If it is asked why maritime transport, answer is quite simple: it costs twenty times less than airline transport, seven times less than road transportation, and three times less than railway transport (MÜsiAD, 2015). In addition to its cost benefits, it must be remembered that the environmental concerns should be taken into consideration. Today, it is even observed that firms could bear higher costs to invest sustainable systems. According to International Maritime Organization (IMO) $2.2 \%$ of total carbon emission is produced by maritime transport and their aim is to halve carbon emission by 2050 (MÜSIAD, 2015).

With the effect of these advantages $75-80 \%$ of the world trade is carried with maritime transport (UTiKAD, 2016) (Koçak, 2012). But the real development that everyone can accept as a revolution in maritime transport is the usage of containers. Containers that have not even been heard before 1960 have now become an important part of maritime trade (Reefke, 2010). If they had not begun to be used, the world would not be "as productive" (Lewis, 2013). From 1968 to today, the daily size of container ships grew by about $1200 \%$ (World Shipping Council, 2016). It is thought that this increase is mainly due to the increase in demand and the benefit of economies of scale. 
At the management of the increasing demand of container transport important tasks wait for ports where a vital node for maritime transport is. In the following sections, first the methods used to measure the activity at the ports will be examined and it is followed by data envelope analysis (DEA) method and the container port based performance comparison of the provincial port authorities.

\section{LITERATURE REVIEW}

The concepts of efficiency and productivity, in some cases can lead to the ambiguity for researchers because of their similarity. Productivity is often defined as a ratio between the volume of the output and the input. The more outputs can be generated with inputs, the more efficient it is.

On the other way, the effectiveness is all about the outputs and tries to answer how much the economic goals are achieved. The relationship between these two concepts is whereas fully effective use of resources means productivity (Suiçmez, 2014).

Dowd and Leschine (1990) summarized the factors that affect productivity and productivity elements in container ports. Accordingly, the elements of terminal operations are introduced and the factors affecting their efficiency are explained (Table 1).

Table 1: Factors Affecting Container Terminals and Productivity Measurements

\begin{tabular}{ll}
\hline $\begin{array}{l}\text { Terminal Operation } \\
\text { Factors }\end{array}$ & Factors affecting productivity \\
\hline $\begin{array}{l}\text { Container Area } \\
\text { Crane }\end{array}$ & $\begin{array}{l}\text { Area, Format, Layout, Warehouse Handling Method, Load Density, Waiting Time } \\
\text { Crane characteristics, Operators' ability, Training, Cargo availability, Distortions, Terminal } \\
\text { support defects }\end{array}$ \\
$\begin{array}{l}\text { Operating hours of operation, Degree of automation, Vessel accessibility, Number of lanes } \\
\text { Dock }\end{array}$ & $\begin{array}{l}\text { Ship schedule, Number of berths, Number of crane } \\
\text { Staff }\end{array}$ \\
Number of job shifts, Work and safety rules, Personnel capabilities, Training and \\
motivation, Ship characteristics
\end{tabular}

Source: Dowd \& Leshine, 1990

Efficiency measurement methods are divided into parametric and nonparametric methods. Parametric methods: stochastic frontier analysis, distribution free analysis, and thick frontier approach. Non parametric methods are free disposal hull and data envelopment approaches (Çağlar \& Oral, 2011).

A bibliometric study on the transport is done by Cavaignac and Petiot (2016). This study is based on this literature. They have summarized data envelopment at seaport studies based on most cited articles. The study by Tongzon (2001) is the most cited one. In this study constant returns to scale was used. Inputs were selected as number of cranes, number of docks for container shipment, number of trailers, waiting time and number of staff. Handled container on the basis of Twenty-foot Equivalent Unit (TEU) and operating time were selected as output. At the second study again constant returns to scale was used this time by Roll and Haynuth (1993). In Roll and Haynuth (1993), constant return to scale approach is used with inputs as number of staff, capital and type of load whereas amount of load, number of ships, customer satisfaction and service level as outputs. Culliane et al. (2006) compares stochastic frontier approach and DEA to measure the technical efficiency of container ports. They used terminal length and area, number of quayside gantry, number of yard gantry and number of straddle carrier as inputs and container throughput for the output. Martinez-Budria et al. (1999) used variable return to scale approach in DEA. Labor expenditures, depreciation charges and other expenditures for input whereas total cargo moved through the docks and revenue are used for the outputs of the model. Culliane et al. (2004) included their study quay length, terminal area, number of deck, number of quay gantry cranes, and the number of straddle carriers as inputs and throughput (TEU) as output. Barros and Athanassiou (2004) used DEA to measure effectiveness of Greek and Portuguese ports. In this study both constant return to scale (CRS) and variable return scale (VRS) are used. Number of work force and capital are used as inputs and total handled load as TEU and number of ships are used as outputs. The next study on the list is studied by Turner et al. (2004). In this study North American ports effectiveness is measured at 19841997. Single output is used which is total load based on TEU and quay length, terminal area and number of crane are the inputs. Valentine and Gray (2001) are used constant return to scale DEA based on total quay length and container quay length as inputs and TEU based handled container and ton based total amount of load as outputs. The following study is done by Cullinane, Song and Wang (2005) with both DEA and free disposal hull. Quay length, terminal area, the number of cranes on the berth and on the terminal, the number of gantry cranes and the number of containers handled on a TEU basis are the data at the study. The las study on the list is done by Park and De (2004) with both VRS and CRS. Berth capacity and ton based load capacity are inputs total ton based load, number of vessels, and customer satisfaction are outputs.

\section{DATA ENVELOPMENT ANALYSIS}

Data Envelopment Analysis (DEA) is a non-parametric method based on linear programming approach that calculates the relative efficiency of multiple decision-making units (DMU). Main advantage of non-parametric methods is it can handle multiple inputs and outputs. In general DEA models can be classified as input oriented and output oriented. Input-oriented model focuses on the minimization of inputs and calculates the degree to which each DMU can reduce the quantities of utilized inputs with fixed outputs. 
On the other hand, the output-oriented model calculates efficiency as the percentage increase in outputs that is feasible by a given available quantity of inputs. This decision should base on the nature of the application. If the decision makers control on the inputs are relatively small or even non exist then output-oriented models can be used; whereas if one cannot control the outputs then input-oriented models should be used (Özden, 2008; Tosun \& Aktan, 2010). (Özden, 2008).

The basic DEA model developed by Charnes, Cooper and Rhodes (CCR) has the assumption of constant returns to scale (CRS) for inputs and outputs. In this model, when the inputs have changed the outputs must change with the same ration. Banker, Charnes and Cooper developed the BCC model which take into the variable returns to scale (VRS). In VRS, model evaluates the increasing, constant or decreasing returns to scale would affect the DMU efficiency (Tektüfekçi, 2010; Taşköprü \& Erpolat, 2016; Mostafa, 2009)

\section{FINDINGS AND DISCUSSIONS}

Different studies used different inputs and outputs to measure the port efficiency, which can be seen in literature survey and Table 1. Right variables must be selected to ensure the appropriateness of the study. In this study terminal area, number of docks and maximum handling capacity (year/TEU) for inputs; yearly container throughput for the output. Data is obtained through each harbors' web page or their managers. All the data is based on 2016 statistics. Trabzonport harbor cannot be reached in the data gathering process, therefore it's omitted in the study.

In DEA, necessity condition is there should be adequate DMUs. Although different opinions can be seen in literature, Vassiloplu and Giokas (1990) suggested that at least three times of the sum of inputs and outputs should be used in an application. In this study 12 DMUs are used, therefore.

Table 2: Data Set Inputs \& Output

\begin{tabular}{lccc|}
\cline { 2 - 4 } & Terminal Area & $\begin{array}{c}\text { Inputs } \\
\text { Number of Quay for } \\
\text { Container Handling }\end{array}$ & $\begin{array}{c}\text { Container Handling } \\
\text { Capacity (TEU) }\end{array}$ \\
\hline Aliağa (DMU1) & 88300 & 7 & 1630000 \\
Throughput (TEU)
\end{tabular}

In Table 2 the data as inputs and output is given in summary based on port authorities in other words as decision making units (DMU). 
Table 3: Detailed Dataset of Turkish Container Ports Input and Output Variables

\begin{tabular}{|c|c|c|c|c|}
\hline & Terminal Area $\left(\mathrm{m}^{2}\right)$ & $\begin{array}{l}\text { Number of } \\
\text { Docks }\end{array}$ & Capacity (year/TEU) & Container Throughput \\
\hline \multicolumn{5}{|c|}{ Aliağa Port Authority } \\
\hline Egegaz & 283000 & 2 & 680000 & \multirow{3}{*}{641845} \\
\hline Nemport & 88300 & 2 & 450000 & \\
\hline Petkim & 169024 & 3 & 500000 & \\
\hline \multicolumn{5}{|c|}{ Ambarlı Port Authority } \\
\hline Akçansa & 40000 & 2 & 100000 & \multirow{4}{*}{2780168} \\
\hline Mardaş & 330000 & 2 & 1300000 & \\
\hline Kumport & 402115 & 5 & 2100000 & \\
\hline Marport & 170000 & 2 & 950000 & \\
\hline \multicolumn{5}{|c|}{ Antalya Port Authority } \\
\hline Port Akdeniz & 166800 & 2 & 500000 & 172064 \\
\hline \multicolumn{5}{|c|}{ Bandırma Port Authority } \\
\hline Çelebi & 268348 & 4 & 50000 & 11289 \\
\hline \multicolumn{5}{|c|}{ Gemlik Port Authority } \\
\hline Borusan & 360000 & 2 & 400000 & \multirow{4}{*}{693164} \\
\hline Yılfert & 15853 & 2 & 500000 & \\
\hline Rodaport & 219600 & 4 & 170000 & \\
\hline Gemport & 655000 & 8 & 600000 & \\
\hline \multicolumn{5}{|c|}{ İskenderun Port Authority } \\
\hline Assan Port & 140000 & 2 & 250000 & \multirow{2}{*}{375034} \\
\hline Limak Port & 1000000 & 5 & 3000000 & \\
\hline \multicolumn{5}{|c|}{ İstanbul Port Authority } \\
\hline Haydarpaşa & 343420 & 6 & 655000 & 110332 \\
\hline \multicolumn{5}{|c|}{ İzmir Port Authority } \\
\hline Alsancak & 902000 & 10 & 549000 & 679905 \\
\hline \multicolumn{5}{|c|}{ Kocaeli Port Authority } \\
\hline Evyap & 265000 & 4 & 855000 & \multirow{4}{*}{1143008} \\
\hline Limaş & 120000 & 2 & 200000 & \\
\hline Safiport Derince & 450000 & 4 & 1500000 & \\
\hline Gemport & 700000 & 6 & 1200000 & \\
\hline \multicolumn{5}{|c|}{ Mersin Port Authority } \\
\hline $\begin{array}{c}\text { Mersin International } \\
\text { Port }\end{array}$ & 112000 & 13 & 2600000 & 1406400 \\
\hline \multicolumn{5}{|c|}{ Samsun Port Authority } \\
\hline Samsunport & 445000 & 3 & 250000 & 52106 \\
\hline \multicolumn{5}{|c|}{ Tekirdağ Port Authority } \\
\hline Tekirdağ Liman İşletmesi & 118563 & 5 & 152000 & \multirow{2}{*}{680271} \\
\hline Asyaport & 300000 & 2 & 2500000 & \\
\hline
\end{tabular}

In table 3 detailed data is shared to show inputs of ports by one by one before we get the port authority sum. WinDEAP program is used for the analysis. The inputs used in the harbors are mostly high value equipment or instruments, so it's nearly impossible to change the amount of them. For this reason, output-oriented model is selected. Also to analyze the effects of the scale economics, variable return to scale approach is used. Therefore, in the study harbor authority's relative efficiencies are measured. For each input variable, the sum of the individual harbors is used for the input of the corresponding harbor authority.

Table 4: Summary Statistics of the Variables

\begin{tabular}{lcccc}
\hline & Min & Max & Average & Standard deviation \\
\hline Terminal Area $\left(\boldsymbol{m}^{\mathbf{2}}\right)$ & 88300 & 1535000 & 634333,25 & 137017,57 \\
Number of Quay & 2 & 16 & 8,5 & 1,31 \\
Capacity & 50000 & 4450000 & 1734250 & 382661,35 \\
Container Throughput & 11289 & 2780168 & 728798,8 & 214779,3 \\
\hline
\end{tabular}


In table 4 summary statistics of inputs and output is listed, where minimum and maximum, average and standard deviation of data set is shown.

Table 5: Port Authority's Effectiveness at 2016

\begin{tabular}{lccccc}
\hline $\begin{array}{l}\text { Harbour } \\
\text { Management }\end{array}$ & $\begin{array}{c}\text { Constant Return } \\
\text { to Scale }\end{array}$ & $\begin{array}{c}\text { Variable Return } \\
\text { to Scale }\end{array}$ & Scale Efficiency & Return to Scale & Summary of Peers \\
\hline Aliağa & 0,793 & 1 & 0,793 & Increase & 0 \\
Ambarlı & 1 & 1 & 1 & - & 4 \\
Antalya & 0,508 & 1 & 0.508 & Increase & 3 \\
Bandırma & 0,182 & 1 & 0.508 & Increase & 1 \\
Gemlik & 0,485 & 0,540 & 0,899 & Decrease & 0 \\
İskenderun & 0,212 & 0,231 & 0,916 & Increase & 0 \\
İstanbul & 0,222 & 0,277 & 0,800 & Increase & 0 \\
İzmir & 1 & 1 & 1 & - & 4 \\
Kocaeli & 0,579 & 0,649 & 0,892 & Decrease & 0 \\
Mersin & 1 & 1 & 1 & - & 1 \\
Samsun & 0,209 & 1 & 0,209 & Increase & 0 \\
Tekirdağ & 0,406 & 0,425 & 0,955 & Increase & 0 \\
Ortalama & 0,550 & 0,425 & 0,763 & & \\
\hline
\end{tabular}

In table 5 it can be seen that Ambarlı, İzmir and Mersin harbors are fully efficient in constant return to scale, whereas Aliağa, Ambarlı, Antalya, Bandırma, İzmir, Mersin and Samsun harbors have full efficiency in variable return to scale. Scale efficiency is defined as the ratio of CRS to VRS. It is the expression of whether a DMU is operating at its optimal size. It's the indicator of the relation between economics of scale and efficiency (Behioğlu \& Özcan, 2009). With increase in the return to scale, an increase in scale of the DMU reflects the technical efficiency progress. On the other hand, if a DMU has decrease in the return to scale, decrease in its scale means technical efficiency increase. From 11 DMUs, Antalya, Ambarlı and Izmir are the most taken as reference.

Table 6: Reference Set of Port Authorities

\begin{tabular}{|c|c|c|c|c|}
\hline Port Authority & \multicolumn{4}{|c|}{ The Port Authorities that should be imitated and rates } \\
\hline Aliağa & Aliağa & & & \\
\hline Ambarlı & Ambarlı & & & \\
\hline Antalya & Antalya & & & \\
\hline Bandırma & Bandırma & & & \\
\hline Gemlik & İzmir $(0,713)$ & Ambarlı $(0,287)$ & & \\
\hline İskenderun & Ambarlı $(0,556)$ & Antalya $(0,444)$ & & \\
\hline İstanbul & Mersin $(0,150)$ & İzmir $(0,199)$ & Bandırma(0,378) & Antalya $(0,273)$ \\
\hline İzmir & İzmir & & & \\
\hline Kocaeli & İzmir $(0,486)$ & Ambarlı $(0,514)$ & & \\
\hline Mersin & Mersin & & & \\
\hline Samsun & Samsun & & & \\
\hline Tekirdă̆ & Ambarlı $(0,545)$ & İzmir $(0,012)$ & Antalya $(0,443)$ & \\
\hline
\end{tabular}

In table 6, reference set for each harbor authority is given. Since Aliağa, Ambarlı, Antalya and Bandırma fully effective their references are their themselves. Others have different reference port authorities and the rate of imitation to be fully effective.

Tablo 7: Expected Outputs According to VRS Output Oriented Analysis

\begin{tabular}{lccc}
\hline Port Authority & $\begin{array}{c}\text { Real Output: Total Handled } \\
\text { Container (TEU) }\end{array}$ & $\begin{array}{c}\text { Expected Amount to Be Fully } \\
\text { Effective }\end{array}$ & Percentage Change \\
\hline Aliağa & 641845 & 641845 & - \\
Ambarlı & 2780168 & 2780168 & - \\
Antalya & 172064 & 172064 & - \\
Bandırma & 11289 & 11289 & - \\
Gemlik & 693164 & 1283441 & 46 \\
İskenderun & $\mathbf{3 7 5 0 3 4}$ & 1621011 & 77 \\
İstanbul & 110332 & 397790,5 & $\mathbf{7 2}$ \\
İzmir & 679905 & 679905 & - \\
Kocaeli & 1143008 & 1759917 & 35
\end{tabular}




\begin{tabular}{lccc} 
Mersin & 1406400 & 1406400 & - \\
Samsun & 52106 & 52106 & - \\
Tekirdağ & $\mathbf{6 8 0 2 7 1}$ & $\mathbf{1 5 9 8 8 1 5}$ & $\mathbf{5 7}$ \\
\hline
\end{tabular}

In Table 7, the improvements for the non-efficient DMUs are given. Actual output, desired output for being fully efficient and the relative change is seen in the table. It's seen that İskenderun port authority is the least efficient among the 12 DMUs. They should have been handled 1.621.011 TEU with their inputs, which is $77 \%$ higher than their actual performance.

\section{CONCLUSION}

Although, it is very important to measure the efficiency, enlightening the inefficiency sources should also be important to effectively utilize the rare resources. Therefore, using DEA is a simple tool to measure the efficiency in port authorities as a managerial tool to evaluate their performance. Classification results can be used for the inefficient ports' managers for better using their resources, and in this way, these ports' are able to give better service to their customers. In addition, administrations can use these results to see whether the dedicated resources are used in proper ways. Perhaps the main limitation of this study is the selection of input and output variables. A comprehensive literature research is done for this purpose, but it should be known that selecting different variables can affect the efficiency scores of DMUs.

In recent years with the privatization of ports, ports activities, investments, and objectives has altered. Nowadays most ports open new quays and invest cranes to increase their capacity. Most probably 2017 input data would be higher than 2016's data. In this study port authority's efficiency in 2016 is compared by the analysis of data envelopment analysis. With respect to literature review determined inputs were terminal area, number of quays, maximum capacity of ports and the output was total container throughput. Results show that Ambarlı and Izmir port authority are the most efficient and the most referenced ones.

Future studies can compare the activities of oversea ports which are at similar geographical location like all ports at Aegean Sea. In addition to container throughput output, container turnover rate, customer satisfaction, and service level can be used as outputs to improve results as often mentioned in literature.

\section{REFERENCES}

Baysal, M. E., Uygur, M., \& Toklu, B. (2004). Veri Zarflama Analizi ile TCDD limanlarinda bir etkinlik ölçümü çalışması. Gazi Üniv. Müh. Mim. Fak. Der., 19(4), 437-442.

Behioğlu, S., \& Özcan, G. (2009). Veri Zarflama Analizi ve Bankacılık Sektöründe Bir Uygulama. Süleyman Demirel Üniversitesi iktisadi ve Idari Bilimler Fakültesi Dergisi, 14(3), 301-326.

Berksoy, T. (2016, Aralık 27). 2016 Yılında Küresel Ekonomi. Dünya: http://www.dunya.com/kose-yazisi/2016-yilinda-kuresel-ekonomi/343270 adresinden alındı

Cavaignac, L., \& Petiot, R. (2016). A quarter century of Data Envelopment Analysis applied to the transport sector: A bibliometric analysis. SocioEconomic Planning Sciences, 1-13.

Cullinane, K., Song, D. W., \& Wang, T. (2005). The Application of Mathematical Programming Approaches to Estimating Container Port Production Efficiency. Journal of Productivity Analysis, 24(1), 73-92.

Cullinane, K., Song, D. W., Ji, P., \& Wang, T. F. (2004). An Application of DEA Windows Analysis to Container Port Production. Review of network Economics, 3(2), 184-206.

Cullinane, K., Wang, T. F., Song, D. W., \& Ji, P. (2006). The Technical Efficiency of Container Ports: Comparing Data Envelopment Analysis and Stochastic Frontier Analysis. Transportation Research Part A: Policy and Practice, 354-374.

Çağlar, V., \& Oral, E. Z. (2011, Kasım 20-23). Liman Verimlilik ve Etkinlik Ölçme Yöntemlerinin Analizi. 7. Kıyı Mühendisliği Sempozyumu , s. 665-676.

Dowd, T. J., \& Leshine, T. M. (1990). Container terminal productivity: a perspective. Maritime Policy \& Management: The flagship journal of international shipping and port research, 17(2), 107-112.

Ekodialog. (2017). Verimlilik Nedir, Verimlilik Çeşitleri ve Verimlilik Ölçümü. Özgün Ekonomi ve Makale Arşivi: http://www.ekodialog.com/Konular/Verimlilik_nedir.html adresinden alındı

Koçak, I. H. (2012). Dünyada ve Türkiye'de Ekonomik Gelişmeler ve Deniz Ticaretine Yansımları. Ankara: T.C. Ulaştırma Denizcilik ve Haberleşme Bakanlığı Deniz Ticareti Genel Müdürlüğü.

Lewis, O. (2013, Ocak 26). Container Investment. http://containerinvestment.info/the-important-role-of-shipping-containers-in-the-economy/ adresinden alındı 
Martinez-Budria, E., Diaz-Armas, R., Navarro-Ibanez, M., \& Ravelo-Mesa, T. (1999). A study of the efficiency of Spanish Port Authorities using Data Envelopment Analysis. International Journal of Transport Economics/Rivista internazionale di economia dei trasporti, $237-253$.

MÜSIAD. (2015). Lojistik Sektöründe Sürdürülebilirlik. İstanbul: Müsiad.

Özden, Ü. H. (2008). Veri zarflama analizi (VZA) ile Türkiye'deki vakıf üniversitelerinin etkinliğinin ölçülmesi. Istanbul University Journal of the School of Business, 37(2), 167-185.

Park, R. K., \& De, P. (2004). An Alternative Approach to Efficiency Measurement of Seaports. Maritime Economics \& Logistics, 6(1), 53-69.

Reefke, H. (2010). Simulation of conteiner traffic flows at a metropolitan seeport. Advanced Manufacturing and Sustainable Logistics, $420-431$.

Suiçmez, H. (2014). Verimlilik ve Etkinlik Terimleri (Tarihsel Bakış). Mülkiye, 169-183.

Taşköprü, V., \& Erpolat, S. (2016, Mart). Klasik Veri Zarflama Analizi ile Kategorik Veri Zarflama Analizi Modellerinin Enerji Verimliliği ÜZerinde Karşılaştırmalı İncelenmesi. Yüksek Lisans Tezi. İstanbul: T.C. Mimar Sinan Güzel Sanatlar Üniversitesi Fen Bilimleri Enstitüsü.

Tektüfekçi, F. (2010). IMKB'ye Kayıtlı Halka Açık Teknoloji Şirketlerinde Finansal Etkinliğin Veri Zarflama Analizi (VZA) ile Değerlendirilmesi. Organizasyon ve Yönetim Bilimleri Dergisi, 2(2), 69-77.

The World Bank. (2017, Ocak 10). The World Bank. Zayıf Yatırım Düzeyine Rağmen Küresel Büyüme Yüzde 2,7'ye Yaklaşıyor: http://www.worldbank.org/tr/news/press-release/2017/01/10/global-growth-edges-up-to-2-7-percent-despite-weak-investment adresinden alındı

Tongzon, J. (2001). Efficiency measurement of selected Australian and other international ports using data envelopment analysis. Transportation Research Part A: Policy and Practice, 107-122.

Tosun, Ö., \& Aktan, H. E. (2010). SSK Hastanelerinin Sağlık Bakanlığı'na Devrinin Hastane Verimlilikeri Üzerine Etkileri. Tisk Akademi, 113-129.

Turner, H., Windle, R., \& Dresner, M. (2004). North American Containerport Productivity: 1984-1997. Transportation Research Part E: Logistics and Transportation Review, 40(4), 339-356.

UTIKAD. (2016, Mayıs 24). Gündem. UTIKAD: http://www.utikad.org.tr/haberler/?id=13545 adresinden alındı

Vassiloglou, M., \& Giokas, D. (1990). A Study of The Relative Efficiency of Bank Branches: An Application of Data Envelopment Analysis. Journal of Operational Research Society, 41(7), 591-597.

World Shipping Council. (2016). Container Ship Design. About the industry: http://www.worldshipping.org/about-the-industry/linerships/container-ship-design adresinden alındı 